\title{
Arthur Robinson and the OSS
}

\section{A Letter from Lawrence Martin}

January 5, 1946

Mr. E.F. Bean

State Geologist

Science Hall

Madison, Wisconsin

Dear Earnie:

Major Arthur H. Robinson, your new colleague at the University of Wisconsin, will be arriving and taking up office during the present month. You and he will have many common associations and interests and I know you will enjoy and profit by working with him.

Of all the American geographers who worked in Washington during the war Robbie rose the highest from the lowest start. He came as a draftsman; he ended as the Chief of the Map Division of the Office of Strategic Services of the Joint Chiefs of Staff; President Roosevelt took him to international conferences at Quebec, at Casablanca, at Cairo, and again at Quebec. He built up the Map Division from a puny waif that had to borrow all its maps from the Library of Congress to a well balanced map depot of almost 2,000,000 maps, atlases, and geographical documents. He created a section of Cartography which compiled and printed better war maps than any other federal institution. Before the collapse of Italy, Germany, Japan, and their satellites he had map outposts in all feasible places in Europe, Asia, and Africa staffed my professional American geographers and producing timely and authoritative maps as well as collecting maps for the armed forces and also for the OSS workers in Washington. There were upwards of 180 of these assistants of Robinson abroad. During the fighting days it was Robinson's assistants and not Army's Military Intelligence of the General Staff who made the maps for the Joint Chiefs of Staff; it was Robinson's lad and not the Army Engineers Map Service or the General Staff's Military Intelligence that kept up the war situation maps for the Secretary of War and Chief of Staff. And after the last gun was fired his Map Division in OSS was not discontinued for Robinson had built so well that the old line agencies wanted to swallow up his collections and apparatus and cartological procedures. And as it turned out Robinson's Map Division of OSS swallowed the State Department's Division of Geography and Cartography which his successor will run within the Department of State.

That's somp'n.

My regards to your family, your several collages, and anybody in Madison who remembers me without loathing.

Always yours,

Lawrence Martin 